\title{
Regulation of Human Breast Cancer by the Long Non-Coding RNA H19
}

\author{
Jordan Collette ${ }^{1,2}$, Xuefen Le Bourhis ${ }^{1,2}$ and Eric Adriaenssens 1,2,* \\ 1 INSERM U908, 59655 Villeneuve d'Ascq, France; jorkan62@gmail.com (J.C.); \\ xuefen.lebourhis@univ-lille1.fr (X.L.B.) \\ 2 University of Lille, 59655 Villeneuve d'Ascq, France \\ * Correspondence: eric.adriaenssens@univ-lille1.fr; Tel.: +333-204-340-38
}

Received: 3 October 2017; Accepted: 30 October 2017; Published: 3 November 2017

\begin{abstract}
Breast cancer is one of the most common causes of cancer related deaths in women. Despite the progress in early detection and use of new therapeutic targets associated with development of novel therapeutic options, breast cancer remains a major problem in public health. Indeed, even if the survival rate has improved for breast cancer patients, the number of recurrences within five years and the five-year relative survival rate in patients with metastasis remain dramatic. Thus, the discovery of new molecular actors involved in breast progression is essential to improve the management of this disease. Numerous data indicate that long non-coding RNA are implicated in breast cancer development. The oncofetal lncRNA H19 was the first RNA identified as a riboregulator. Studying of this lncRNA revealed its implication in both normal development and diseases. In this review, we summarize the different mechanisms of action of $H 19$ in human breast cancer.
\end{abstract}

Keywords: lncRNA; H19; breast cancer; non-coding RNA

\section{Introduction}

Breast cancer is the most common tumor in women and caused 508,000 deaths worldwide in 2011 [1]. Recent advances in molecular classification of this pathology allowed personalized-treatment of patients and better outcomes, like the use of Herceptin in patients with overexpression of human epidermal growth factor receptor 2 (Her-2) [2]. However, some classes of breast cancer such as triple-negative, which is characterized by neither expression of progesterone receptor (PR), estrogen receptor, nor Her-2, remains a poor prognostic for patients. The discovery of new molecular actors involved in the regulation of breast cancer development is essential to improve the management of this disease. During the last decades, plenty of non-coding RNAs have been involved in breast cancer development [3]. The study of non-coding RNAs could lead to the development of new therapeutic strategies and better outcomes for patients with triple negative breast cancer, and more generally to patients with cancer.

The Encyclopedia of DNA Elements (ENCODE) consortium revealed that up to $80 \%$ of the human genome is transcribed into functional RNAs, but only $2 \%$ of the genome codes for proteins [4-6]. RNAs without coding potential are referred to as non-coding RNAs (ncRNAs). Based on theirs lengths, they can be classified into two classes: small ncRNAs ( $<200 \mathrm{nt})$ and long ncRNAs ( $>200 \mathrm{nt})$. Small ncRNAs include microRNAs (miRs), small interfering RNAs (siRNAs), PIWI-interacting RNAs (piRNAs) or small nucleolar RNA (snoRNAs). miRs, siRNAs, and piRNAs were shown to mainly act as negative regulators of gene expression, whereas snoRNA serves as a guide to induce chemical modification of other RNAs [7]. Recently, Hon et al. identified 19,175 potentially functional lncRNAs in the human genome [8]. The majority of IncRNAs shared similarities with mRNA: they are transcribed by RNA polymerase II; $5^{\prime}$ capped; $3^{\prime}$ polyadenylated; and could be subjected to splicing $[9,10]$. The IncRNAs are also transcriptionally regulated by transcription factor and epigenetic modifications and their expression is cell-type/tissue specific [8]. 
Implication of lncRNA is well documented in different pathologies, including neurological diseases [11,12], diabetes [13], and cancers [14]. IncRNAs exert their functions through diverse molecular mechanisms such as acting as scaffolds for RNP complex, decoys for transcriptional factors or microRNAs, RNA interference, targeting of transcriptional factor or chromatin modifier protein to specific genomic loci, transcriptional regulation in cis or trans [15]. In this review, we will focus on the implication of $H 19$, the first identified lncRNA, in human breast cancer.

\section{H19 Gene Locus}

The H19/IGF2 locus located at position 11p15.5 is subject to genomic imprinting and is encoded for several transcripts. One of these transcripts, H19, was proposed to act as a riboregulator by Brannan et al. in 1990 and was the first identified lncRNA [16]. Major findings about H19 and its implication in breast cancer are summarized below in a timeline manner (Figure 1).

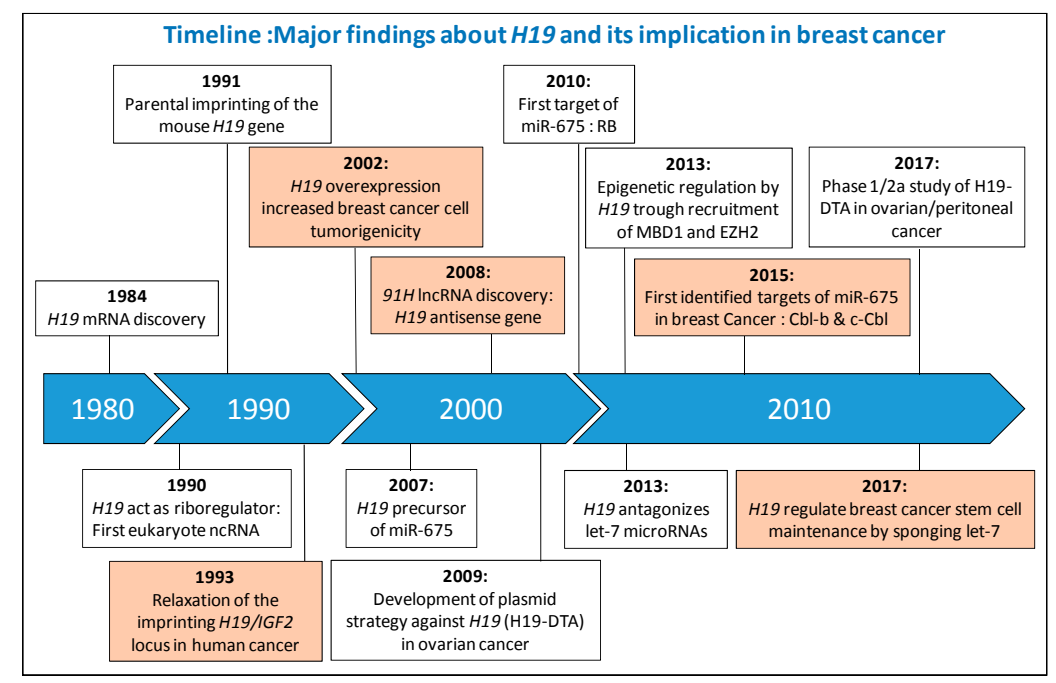

Figure 1. Major finding about $H 19$ and its implication in breast cancer. Information concerning the implication of $H 19$ in breast cancer are colored orange. IGF2, Insulin-like Growth Factor 2; lncRNA, Long Non-Coding RNA; RB, Retinoblastoma; MBD1, Methyl-CpG Binding Domain, EZH2, Enhancer of Zeste Homolog 2; Cbl, Casitas B-lineage Lymphoma; H19-DTA, Plasmid encoding the A chain of diphtheria toxin (DT-A) driven by the regulatory sequences of human H19.

The $H 19$ gene is transcribed by the RNA polymerase II to give raise a polyadenylated, capped and spliced $2.3 \mathrm{~kb}$ RNA. $H 19$ is paternally imprinted and maternally expressed [17]. It is expressed during embryonic development and repressed after birth expect in a few tissues like mammary gland and uterus [18]. Aberrant expression of $H 19$ due to imprinting modification is responsible for developmental diseases. The loss of $H 19$ expression and a biallelic expression of IGF2 are responsible for the Beckwith-Wiedmann syndrome characterized by fetal and postnatal overgrowth and predisposition to pediatric cancers such as Wilm's tumors [19]. Biallelic H19 expression and loss of IGF2 expression can lead to Silver-Russel syndrome characterized by intrauterine and postnatal growth retardation combined with others symptoms [19]. In cancer, H19 is frequently overexpressed and it is associated to many aspect of cancer development [20,21].

In 2007, Cai \& Kullen demonstrated that $H 19$ is a precursor of miR-675 [22]. The two strands of miR-675, miR-675-5p, and miR-675-3p, have been involved in disease development and notably in cancer development (Section 3.1). In the locus H19/IGF2, we have identified the presence of a new IncRNA antisense to $H 19$ gene, named $91 \mathrm{H}$ [23]. This IncRNA is also associated with cancer development in solid-tumors such as breast cancer or osteosarcoma [23,24]. The implication of $H 19$ and $91 H$ in cancer 
is well described and is mediated by different mechanisms characteristics of that observed for other non-coding RNAs. In this review, we will focus on the role of H19 in human breast cancer.

\section{H19 Gene Locus in Human Breast Cancer}

The implication of H19 in tumorigenesis has been reported and H19 is overexpressed in many solid tumors such as prostate, bladder or breast cancers [25-27]. We showed that $H 19$ is overexpressed in $73 \%$ of breast cancer tissues when compared to healthy tissues [28]. Several studies showed that H19 is controlled by steroid hormones in normal and cancerous mammary gland, uterus and prostate [29-31]. In breast cancer, the expression of $H 19$ is higher in Estrogen receptor $(E R \alpha)$ positive cells, but in the ER $\alpha$ negative MDA-MB-231 cell line, ectopic overexpression of $H 19$ is associated with increased proliferation [27,30]. Collectively, these data indicate that $H 19$ favor breast cancer development probably thought different mechanisms discussed below.

\subsection{H19: Precursor of miR-675-5p and miR-675-3p}

The H19-derived miR-675 gives rise to two functional microRNA, miR-675-5p, and miR-675-3p with different validated targets. The implication of miR- 675 in cancer was firstly shown by Tsang WP et al. in colorectal cancer (CRC). By targeting the tumor suppressor retinoblastoma (RB) protein, miR-675-5p regulates the CRC development [32]. In human breast cancer, we have identified two ubiquitin ligase E3, c-Cbl, and Cbl-b, as direct targets of miR-675-5p [33]. The overexpression of miR-675-5p in breast cancer cells lines induced the downregulation of c-Cbl and Cbl-b proteins and increased the stability and the activation of Epidermal growth factor receptor (EGFR) and c-Met. Steady activation of Akt and Erk pathway enhanced the proliferation of human breast cancer and their metastasis abilities in xenograft experiments.

Zhai et al. investigated the expression of miR-675-5p in formalin-fixed paraffin-embedded (FFPE) tissues of 100 breast cancer patients [34]. The authors showed that miR-675 is significantly up-regulated in breast cancer patients compared with controls, but this up-regulation is not correlated with clinical and pathological status including ER and PR expression, age, and lymph node stage. The frequency of miR-675 overexpression was higher in the patients with low histological grade (I and II). Cordero et al. analyzed DNA methylation levels of 517 microRNA encoding genes in prediagnostic peripheral white blood cells of subjects who have developed colorectal cancer or breast cancer (BC) and subjects who remained clinically healthy [35]. They found that eight microRNAs, including miR-675-5p, were differentially methylated in subjects who went on to develop breast cancer. In those subjects, miR-675-5p was significantly hypomethylated suggesting that miR-675-5p could be used as biomarker for breast cancer.

All the known targets of miR-675-5p and miR-675-3p implicated or not in neoplasia are resumed in Table 1.

Table 1. Validated targets of miR-675-5p and miR-675-3p.

\begin{tabular}{cccc}
\hline Targets of miR-675-5p & Cellular Context & Proteins Function & References \\
\hline c-Cbl \& Cbl-b & Breast cancer & Ubiquitin ligase E3 & {$[33]$} \\
\hline HDAC 4/5/6 & $\begin{array}{c}\text { Bone Marrow Mesenchymal } \\
\text { Stem Cells }\end{array}$ & Histone deacetylase & {$[36]$} \\
\hline CaMKIId & Cardiomyocyte hypertrophy & Serine threonine protein kinase & {$[37]$} \\
\hline USP10 & c-kit+ cardiac progenitor cells & Ubiquitin-specific protease & {$[38]$} \\
\hline RB & Colorectal cancer & Cell cycle regulator & {$[32]$} \\
\hline DDB2 & Colon cancer cells & Transcriptional repressor & {$[39]$} \\
\hline VDR & Colon cancer cells & Vitamin D receptor & {$[40]$} \\
\hline VDAC1 & Diabetic cardiomyopathy & Required for mitochondria-mediated apoptosis & {$[41]$} \\
\hline REPS2 & $\begin{array}{c}\text { Esophageal squamous } \\
\text { cell carcinoma }\end{array}$ & Repressor of cell proliferation and migration & {$[42]$} \\
\hline
\end{tabular}


Table 1. Cont.

\begin{tabular}{|c|c|c|c|}
\hline Targets of miR-675-5p & Cellular Context & Proteins Function & References \\
\hline CALN1 & Gastric cancer & Calcium-binding protein & [43] \\
\hline RUNX1 & Gastric cancer & Transcription factor & {$[44,45]$} \\
\hline FADD & Gastric cancer & $\begin{array}{l}\text { Apoptotic adaptor that recruits caspase } \\
\qquad 8 \text { or } 10\end{array}$ & [46] \\
\hline Cadherin 13 & Glioma cell & $\begin{array}{l}\text { Atypical cadherin lacking the } \\
\text { cytoplasmic domain }\end{array}$ & [47] \\
\hline RB \& TWIST1 & Hepatocellular carcinomas & Twist1: Transcription factor & {$[48]$} \\
\hline GPR55 & Non-small cell lung cancer & G protein-coupled receptor & [49] \\
\hline TGF-ß1 & Osteoblast differenciation & Growth factor & [50] \\
\hline TGF-ßB1 & Prostate cancer & Growth factor & [25] \\
\hline NOMO1 & Placental trophoblast cell & Nodal signaling pathway & [51] \\
\hline ATP8A2 & Skeletal cell & $\begin{array}{l}\text { Catalytic component of a P4-ATPase } \\
\text { flippase complex }\end{array}$ & [52] \\
\hline CDC6 & Skeletal muscle & $\begin{array}{l}\text { Essential for the initiation of DNA } \\
\text { replication }\end{array}$ & [53] \\
\hline VDR & Ulcerative Colitis & Vitamin D receptor & [54] \\
\hline Targets of miR-675-3p & Cellular Context & Proteins Function & References \\
\hline Cadherin 11 & Melanogenesis & Type II classical cadherin & [55] \\
\hline MITF & Melanogenesis & Transcription factor & [56] \\
\hline IGF1R & Placenta & Insulin-like growth factor 1 receptor & [57] \\
\hline TGF-ß1 & Osteoblast differenciation & Growth factor & [50] \\
\hline SMAD1 \& SMAD5 & Skeletal muscle & $\begin{array}{l}\text { Intracellular signal transducer and } \\
\text { transcriptional modulator }\end{array}$ & [53] \\
\hline
\end{tabular}

Some of these targets could explain the oncogenic role of H19 in breast cancer. For example, miR- 675 stimulates migration and invasion by targeting TGF- $\beta 1$ in prostate cancer cells, Cadherin 13 in glioma cells, or RUNX1 in gastric cancer cells [42,44,47]. We found that $H 19$ and miR-675 expression enhances breast cancer cell migration $[33,58]$. This could be mediated by targeting the above cited molecules, even if miRNAs targets remain tissue specific. By example, miR-675 was shown to downregulate the expression of RB in human colorectal cancer to promote tumor development [32]. $\mathrm{RB}$ was also demonstrated as a target of miR-675-5p in hepatocellular carcinomas [48]. However, we showed that miR-675-5p doesn't interact with RB mRNA in human breast cancer cell lines [33].

\subsection{Competing Endogenenous RNAs (ceRNAs): Sequestration of miRs by H19}

Tay et al. reported that lncRNA can be in competition with mRNA for common microRNAs and termed such lncRNA transcript as competing endogenous RNAs (ceRNAs) [59]. H19, as numerous lncRNAs, could act by this mechanism. Recently, Peng et al. demonstrated the implication of H19 in maintenance of breast cancer stem cells through the sequestration of let-7 [60]. The lower availability of let-7 increases the expression of its target, the core pluripotency factor LIN28; LIN28 in turn blocks mature let-7 production and enhances the expression of $H 19$ in breast cancer stem cells. In human breast cancer cells lines, $H 19$ upregulates the DNA methyltransferase DNMT1 by sponging miR-152, leading to enhancement of cell proliferation and invasion of the cells [61]. The authors also revealed a correlation between the overexpression of $H 19$ and DNMT1 and the downregulation of miR-152 in human breast tumor tissues. In 2017, Zhou et al. demonstrated that $H 19$ regulates Epithelial-mesenchymal transition (EMT) and Mesenchymal-epithelial transition (MET) by differentially acting as a sponge for the microRNA miR-200b/b and let-7b using a mouse model of spontaneous metastatic breast cancer [62]. Other microRNAs sequestrated by $H 19$ are indicated in Table 2. 
Table 2. Validated miRNAs sponged by H19.

\begin{tabular}{ccc}
\hline miRNAs Sponged by $\mathbf{H 1 9}$ & Cellular Context & References \\
\hline hsa-miR-19a/b & Acute myelocytic leukemia & {$[63]$} \\
miR-29b-3p & Bladder cancer & {$[64]$} \\
miR-152 & Breast cancer & {$[61]$} \\
let-7 & Breast cancer stem cells & {$[60]$} \\
miR-455 & Cardiac fibrosis & {$[65]$} \\
let7 & Endometriosis & {$[66]$} \\
miR-181-d & Gliobastoma & {$[67]$} \\
let-7 & HEK293 & {$[68]$} \\
miR-106-a \& miR-17-5p & Hela Cells, myboblast & {$[69]$} \\
let-7 & Muscle cells & {$[70]$} \\
let-7b \& miR-200b/c & Mouse breast cancer & {$[62]$} \\
miR 141 miR 22 & Osteoblast & {$[71]$} \\
mir-200s & Osteosarcoma & {$[72]$} \\
miR-17-5p & Thyroid cancer & {$[73]$} \\
\hline
\end{tabular}

The impact of $H 19$ on metastasis abilities of the human breast cancer cell could be due to the sponging of these microRNAs. By example, H19 regulates EMT in bladder cancer by sponging miR-29b-3p [64]. In thyroid cancer, $H 19$ promotes proliferation, migration, and invasion of cancer cells through the sponging of miR-17-5p [73]. H19 also regulates tumorigenic abilities of glioblastoma cells by sponging miR-181-d, in acute myleocytic leukemia by sponging has-miR-19a/b and in osteosarcoma by serving as competing endogenous RNA for the miR-200s family [63,67,72].

In conclusion, the lncRNA H19 interacts with miRs pathways not only by being the precursor of miR-675, but also by physically interacting with other miRs to regulate the expression of their targets (Figure 2).

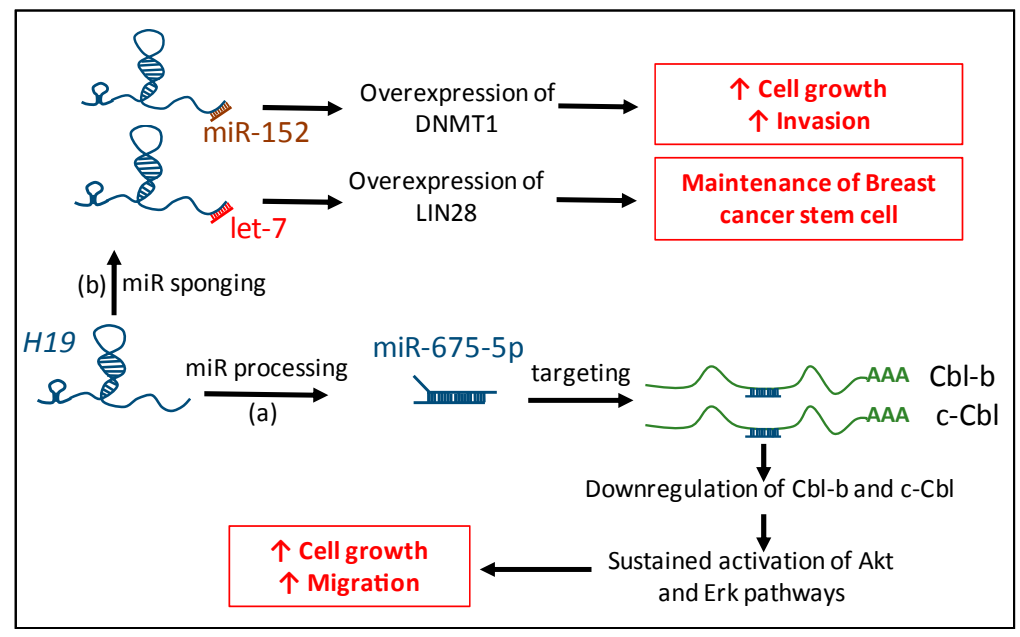

Figure 2. Connection between $H 19$ and microRNAs. H19 is the precursor of miR-675-5p which targets $\mathrm{Cbl}-\mathrm{b}$ and c-Cbl mRNA in breast cancer. Downregulation of $\mathrm{Cbl}-\mathrm{b}$ and c-Cbl protein expression induces sustained activation of Akt and Erk pathways that lead to increased cell growth and migration potential (a). $H 19$ physically interacts with miR-152 and let-7 and impairs their bioavailability to induce the overexpression of their targets, DNMT1 and LIN28, and participle in tumorigenic properties and maintenance of stemness in breast cancer cells (b). Red arrows indicate an increased phenotype.

\subsection{Epigenetics Modification Induced by H19}

Long non-coding RNA could interact with chromatin modifier protein and contribute to epigenetic regulation of gene expression. H19 was shown to interact with the histone methyl transferase Enhancer 
of zeste homolog 2 (EZH2) and epigenetically silenced E-cadherin in bladder cancer and DIRAS3 in diabetic cardiomyopathy [74,75]. Si et al. identified $H 19$ as a factor associated with paclitaxel resistance in ER $\alpha$-positive breast cancer cells. $H 19$ decreases cell apoptosis induced by paclitaxel treatment by inhibiting the transcription of pro-apoptotic genes BIK and NOXA. The recruitment of EZH2 by H19 and its targeting onto the promoter of BIK induce its downregulation. As described in Section 3.2, H19 impairs availability of miR-152 and increases the expression of the epigenetic regulator DNMT1 and so increases proliferation of breast cancer cells lines [61]. However, the epigenetic modification induced by DNMT1 remains unknown. In the embryo, $H 19$ has been shown to physically interact with MBD1 and induce its recruitment at several imprinted genes including IGF2, PEG1, and SLC38A4 [76]. In 2015, Zhou et al. demonstrated that H19 binds to and inhibits S-adenosylhomocysteine hydrolase (SAHH) which carries the synthesis of $S$-adenosylmethionine (SAM), the only source of methyl for methyltransferases and other processes that are methyl-dependent [77]. Modulation of $H 19$ can modify genome wide DNA methylation and knockdown of H19 increased DNMT3B-mediated methylation of the IncRNA-encoding gene Nctc1 within the Igf2-H19-Nctc1 locus.

Taken together, these data revealed that $H 19$ is an important regulator of epigenetic status of target genes. The epigenetic regulation driven by $\mathrm{H} 19$ could be done by physical interaction with chromatin modifier protein or indirectly by regulating their expression.

\subsection{H: H19 Antisense Transcript}

In 2008, we identified a new non-coding transcript within the IGF2/H19 locus which is an antisense gene to $H 19$ named $91 \mathrm{H}$ [23]. This transcript of $120 \mathrm{~kb}$ in humans is an IncRNA expressed in human and mice from the maternal allele. We also showed that $91 \mathrm{H}$ is overexpressed in breast tumors. Further studies demonstrate the implication of $91 \mathrm{H}$ in osteosarcoma [24] and colorectal cancer [78]. Recently, we showed that in breast cancer cells that $91 \mathrm{H}$ exerts oncogenic properties by promoting cell growth, migration, and invasion [79]. In 91H-knockdown cell lines the expression of $H 19$ and IGF2 is reduced through epigenetic modifications on H19/IGF2 locus. These data suggest that $91 \mathrm{H}$ plays an essential role in breast cancer development, but it is possible that $91 \mathrm{H}$ regulation of tumorigenicity requires other factors than $H 19$ or IGF2. Differentiate the implication of $91 \mathrm{H}$ in biological process independently of $H 19$ is not an easy task, but well thought experiments are needed to address the issue.

\subsection{Regulation of Cell Cycle}

Besides the involvement of H19 in EMT, migration, metastasis, and carcinogenesis through the mechanisms described above, $H 19$ plays a key role in the regulation of the cell cycle. The overexpression of H19 in breast cancer cells lines facilitates cell cycle transition G1/S while downregulation of H19 by RNA interference impedes S-phase entry and proliferation [80]. H19 is activated by E2F1 binding (a key factor in the G1/S transition) to two consensus sites on $H 19$ promoter and negatively regulated by E2F6 and RB protein. Interestingly, in human colorectal cancer cell lines, H19 through microRNA downregulates RB protein and increases cell growth [32]. Barsyte-Lovejoy et al. demonstrated that the oncogene c-Myc binds specifically to H19 maternal allele to promote its transcription, leading to proliferation of breast and lung cancerous cells [81]. We have also shown that the tumor suppressor protein and cell cycle regulator p53 negatively regulates $\mathrm{H} 19$ in tumor cells [82]. The interaction between H19 and p53 was also described in other cancers. In gastric cancer cells H19 physically interacts with p53 to induce p53 inactivation [83]. The H19-derived miR-675 negatively regulates p53 through an unknown target in bladder cancer cell [26]. In C-kit ${ }^{+}$cardiac progenitor cells, Cai et al. showed that miR-675 negatively regulates p53 through the targeting of USP10 [38]. Even if the regulation of p53 by H19 in human breast cancer is not yet described, these data, collectively, demonstrate that H19 and miR-675 play a pivotal role in the regulation of cell cycle in cancer as illustrated in Figure 3. 


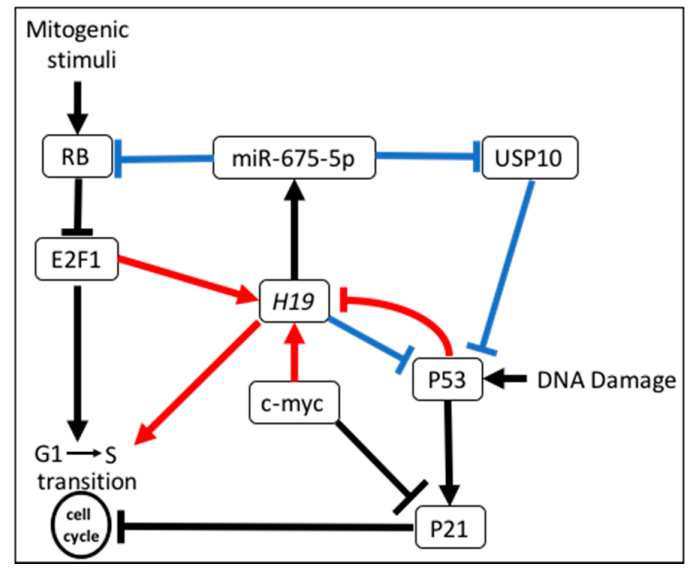

Figure 3. H19 and cell cycle regulation. H19 favors the cell cycle progression through different mechanisms. Mechanisms demonstrated in breast cancer are indicated in red, in other cellular context are indicated in blue. General mechanisms of cell cycle regulation are indicated in black. Arrows indicate positive regulations whereas lines with bars correspond to inhibition.

\section{Conclusions}

H19 is involved in human breast cancer through interaction with protein, microRNAs, H19-derived miR-675-5p, and H19 antisense lncRNA $(91 H)$ but the study of these ncRNAs is not only restrained in cancer cell behavior. Increasing studies have reported their interests as cancer biomarkers and therapeutic targets. In breast cancer, Zhang et al. demonstrated that the expression of H19 is significantly increased in cancer biopsies and plasma compared with healthy controls, plasma H19 levels were significantly correlated with progesterone and estrogen receptors and lymph node metastasis [84]. The plasma level of $H 19$ is higher in patients with gastric cancer compared to normal controls. Lower H19 expression is found in postoperative samples compared to preoperative ones [85]. Higher levels of miR-675 are also found in both tumor samples and gastric juice of patients suffering from gastric cancer [86]. The different implication of H19 in human breast cancer is illustrated in Figure 4.

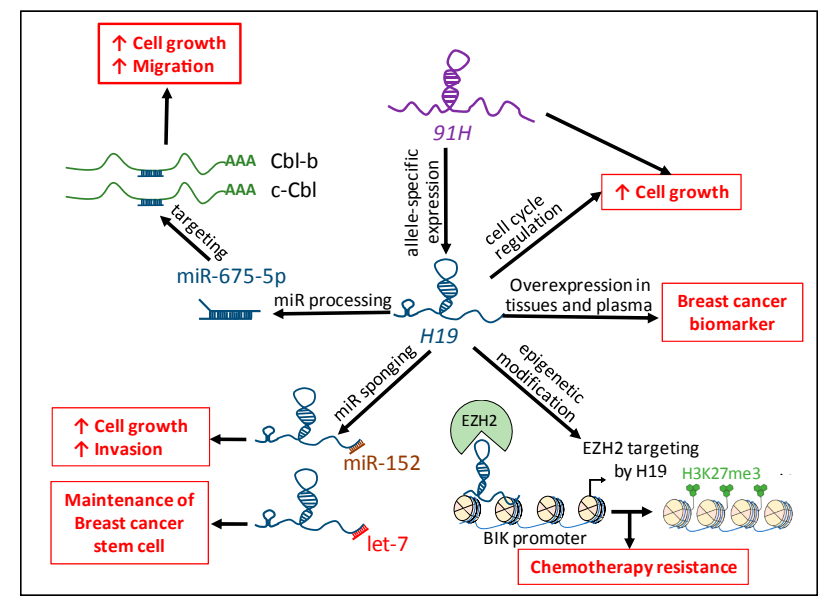

Figure 4. Implication of $H 19$ in human breast cancer. The H19 lncRNA favors breast tumorigenicity by regulating the cell cycle, through the processing of miR-675-5p and the sponging of miR-152 and let-7, and regulating chemotherapy resistance through epigenetic modification. The $H 19$ antisense, $91 H$, allows allele-specific expression of $H 19$ and participates in breast cancer cell biology. H19 and miR-675 are overexpressed in breast cancer tissues and plasma of patients and could be used as tumor biomarkers. H3K27me3: Trimethylation of lysine 27 on histone H3. Red arrows indicate an increased phenotype. 
From a therapeutic perspective, a plasmid-based strategy (DTA-H19/BC-819) to target H19 is presently in a phase $2 \mathrm{~b}$ clinical trial for bladder cancer and in phase $1 / 2 \mathrm{a}$ for ovarian and peritoneal cancer $[87,88]$. Although further studies are needed, the targeting of $H 19$ and miR-675 could provide novel opportunities in the treatment of cancer patients.

Acknowledgments: This work was supported by INSERM, INCA (PLBio 2010-180), Ligue contre le cancer and Cancéropole Nord-Ouest.

Author Contributions: Eric Adriaenssens provided direction during the preparation of this manuscript; Jordan Collette conducted the literature review and drafted the manuscript; Xuefen Le Bourhis reviewed the manuscript and made significant revisions on the drafts.

Conflicts of Interest: The authors declare no conflict of interest.

\section{Abbreviations}

$\begin{array}{ll}\text { RNA } & \text { Ribonucleic Acid } \\ \text { DNA } & \text { Deoxyribonucleic Acid } \\ \text { ENCODE } & \text { Encyclopedia of DNA } \\ \text { ncRNAs } & \text { Non-coding RNAs } \\ \text { lncRNas } & \text { Long non-coding RNAs } \\ \text { miRs } & \text { MicroRNAs } \\ \text { siRNAs } & \text { Small non-coding RNAs } \\ \text { piRNAs } & \text { PIWI-interacting RNAs } \\ \text { snoRNAs } & \text { Small nucleolar RNA } \\ \text { Her-2 } & \text { Human epidermal growth factor receptor 2 } \\ \text { PR } & \text { Progesterone receptor } \\ \text { ER } & \text { Estrogen receptor } \\ \text { IGF2 } & \text { Insulin growth factor 2 } \\ \text { BC } & \text { Breast cancer } \\ \text { CRC } & \text { Colorectal cancer } \\ \text { RB } & \text { Retinoblastoma } \\ \text { DNMT1 } & \text { DNA Methyltransferase 1 } \\ \text { EMT } & \text { Epithelial-mesenchymal transition } \\ \text { MET } & \text { Mesenchymal-epithelial transition } \\ \text { BIK } & \text { BCL2 Interacting Killer } \\ \text { NOXA } & \text { NADPH Oxidase Activator 1 } \\ \text { MBD1 } & \text { Methyl-CpG Binding Domain Protein 1 } \\ \text { PTX } & \text { Paclitaxel } \\ \text { PEG1 } & \text { Paternally-Expressed Gene 1 Protein } \\ \text { SAHH } & \text { S-adenosylhomocysteine hydrolase } \\ \text { E2F1 } & \text { E2F Transcription Factor 1 } \\ \text { CPCs } & \text { c-kit+ cardiac progenitor cells } \\ \text { USP10 } & \text { Ubiquitin Specific Peptidase 10 } \\ & \end{array}$

\section{References}

1. World Health Organization. Global Health Estimates; World Health Organization: Geneva, Switzerland, 2013.

2. Dean-Colomb, W.; Esteva, F.J. Her2-positive Breast Cancer: Herceptin and Beyond. Eur. J. Cancer 2008, 44, 2806-2812. [CrossRef] [PubMed]

3. Cerk, S.; Schwarzenbacher, D.; Adiprasito, J.B.; Stotz, M.; Hutterer, G.C.; Gerger, A.; Ling, H.; Calin, G.A.; Pichler, M. Current status of long non-coding RNAs in human breast cancer. Int. J. Mol. Sci. 2016, 17, 1485. [CrossRef] [PubMed]

4. Birney, E.; Stamatoyannopoulos, J.A.; Dutta, A.; Guigó, R.; Gingeras, T.R.; Margulies, E.H.; Weng, Z.; Snyder, M.; Dermitzakis, T.; Thurman, R.E.; et al. Identification and analysis of functional elements in $1 \%$ of the human genome by the ENCODE pilot project. Nature 2007, 447, 799-816. [CrossRef] [PubMed] 
5. Kapranov, P.; Cheng, J.; Dike, S.; Nix, D.A.; Duttagupta, R.; Willingham, A.T.; Stadler, P.F.; Hertel, J.; Hackermüller, J.; Hofacker, I.L.; et al. RNA maps reveal new RNA classes and a possible function for pervasive transcription. Science 2007, 316, 1484-1488. [CrossRef] [PubMed]

6. Qu, H.; Fang, X. A Brief review on the human encyclopedia of DNA elements (ENCODE) project. Genom. Proteom. Bioinform. 2013, 11, 135-141. [CrossRef] [PubMed]

7. Scott, M.S.; Motoharu, O. From snoRNA to miRNA: Dual function regulatory non-coding RNAs. Biochimie 2011, 93, 1987-1992. [CrossRef] [PubMed]

8. Hon, C.C.; Ramiloski, J.A.; Harshbarger, J.; Bertin, N.; Rackham, O.J.L.; Gough, J.; Denisenko, E.; Schmeier, S.; Poulsen, T.M.; Severin, J.; et al. An Atlas of human long non-coding RNAs with accurate $5^{\prime}$ ends. Nature 2017, 543, 199-204. [CrossRef] [PubMed]

9. Wu, H.; Yang, L.; Chen, L.L. The diversity of long non-coding RNAs and their generation. Trends Genet. 2017, 33, 540-552. [CrossRef] [PubMed]

10. Quinn, J.J.; Chang, H.Y. Unique features of long non-coding RNA biogenesis and function. Nat. Rev. Genet. 2015, 17, 47-62. [CrossRef] [PubMed]

11. Luo, Q.; Chen, Y. Long noncoding RNAs and Alzheimer's disease. Clin. Interv. Aging 2016, 11, 867-872. [CrossRef] [PubMed]

12. Huang, X.; Luo, Y.L.; Mao, Y.S.; Ji, J.J. The link between long noncoding RNAs and depression. Prog. Neuropsychopharmacol. Biol. Psychiatry 2017, 73, 73-78. [CrossRef] [PubMed]

13. Mirza, A.H.; Kaur, S.; Pociot, F. Long non-coding RNAs as novel players in $\beta$ cell function and type 1 diabetes. Hum. Genom. 2017, 11, 17. [CrossRef] [PubMed]

14. Bhan, A.; Soleimani, M.; Mandal, S.S. Long Noncoding RNA and cancer: A new paradigm. Cancer Res. 2017, 77, 3965-3981. [CrossRef] [PubMed]

15. Angrand, P.O.; Vennin, C.; Le Bourhis, X.; Adriaenssens, E. The role of long non-coding RNAs in genome formatting and expression. Front. Genet. 2015, 6. [CrossRef] [PubMed]

16. Brannan, C.I.; Dees, E.C.; Ingram, R.S.; Tilghman, S.M. The product of the H19 gene may function as an RNA. Mol. Cell. Biol. 1990, 10, 28-36. [CrossRef] [PubMed]

17. Bartolomei, M.S.; Zemel, S.; Tilghman, S.M. Parental imprinting of the mouse H19 gene. Nature 1991, 351, 153-155. [CrossRef] [PubMed]

18. Vennin, C.; Dahmani, F.; Spruyt, N.; Adriaenssens, E. Role of long non-coding RNA in cells: Example of the H19/IGF2 locus. Adv. Biosci. Biotechnol. 2013, 4, 34-44. [CrossRef]

19. Delaval, K.; Wagschal, A.; Feil, R. Epigenetic deregulation of imprinting in congenital diseases of aberrant growth. BioEssays 2006, 28, 453-459. [CrossRef] [PubMed]

20. Rainier, S.; Johnson, L.A.; Dobry, C.J.; Ping, A.J.; Grundy, P.E.; Feinberge, A.P. Relaxation of imprinted genes in human cancer. Nature 1993, 362, 747-749. [CrossRef] [PubMed]

21. Raveh, E.; Matouk, I.J.; Gilon, M.; Hochberg, A. The H19 long non-coding RNA in cancer initiation, progression and metastasis-A proposed unifying theory. Mol. Cancer 2015, 14. [CrossRef] [PubMed]

22. Cai, X.; Cullen, B.R. The Imprinted H19 noncoding RNA is a primary microRNA precursor. RNA 2007, 13, 313-316. [CrossRef] [PubMed]

23. Berteaux, N.; Aptel, N.; Cathala, G.; Genton, C.; Coll, J.; Daccache, A.; Spruyt, N.; Hondermarck, H.; Dugimont, T.; Curgy, J.J.; et al. A novel H19 antisense RNA overexpressed in breast cancer contributes to paternal IGF2 expression. Mol. Cell. Biol. 2008, 28, 6731-6745. [CrossRef] [PubMed]

24. Xia, W.K.; Lin, Q.F.; Shen, D.; Liu, Z.L.; Su, J.; Mao, W.D. Clinical implication of long noncoding RNA 91H expression profile in osteosarcoma patients. OncoTargets Ther. 2016, 9, 4645-4652. [CrossRef]

25. Zhu, M.; Chen, Q.; Liu, X.; Sun, Q.; Zhao, X.; Deng, R.; Wang, Y.; Huang, J.; Xu, M.; Yan, J.; et al. IncRNA H19/miR-675 axis represses prostate cancer metastasis by targeting TGFBI. FEBS J. 2014, 281, 3766-3775. [CrossRef] [PubMed]

26. Liu, C.; Chen, Z.; Fang, J.; Xu, A.; Zhang, W.; Wang, Z. H19-derived miR-675 contributes to bladder cancer cell proliferation by regulating P53 activation. Tumor Biol. 2016, 37, 263-270. [CrossRef] [PubMed]

27. Lottin, S.; Adriaenssens, E.; Dupressoir, T.; Bertaux, N.; Montpellier, C.; Coll, J.; Dugimont, T.; Curgy, J.J. Overexpression of an ectopic $\mathrm{H} 19$ gene enhances the tumorigenic properties of breast cancer cells. Carcinogenesis 2002, 23, 1885-1895. [CrossRef] [PubMed] 
28. Adriaenssens, E.; Dumont, L.; Lottin, S.; Bolle, D.; Leprêtre, A.; Delobelle, A.; Bouali, F.; Dugimont, T.; Coll, J.; Curgy, J.J. H19 overexpression in breast adenocarcinoma stromal cells is associated with tumor values and steroid receptor status but independent of P53 and Ki-67 expression. Am. J. Pathol. 1998, 153, 1597-1607. [CrossRef]

29. Berteaux, N.; Lottin, S.; Adriaenssens, E.; Coppenolle, F.W.; Leroy, X.; Coll, J.; Dugimont, T.; Curgy, J.J. Hormonal regulation of $H 19$ gene expression in prostate epithelial cells. J. Endocrinol. 2004, 183, 69-78. [CrossRef] [PubMed]

30. Basak, P.; Chatterjee, S.; Weger, S.; Bruce, M.C.; Murphy, L.C.; Raouf, A. Estrogen regulates luminal progenitor cell differentiation through $H 19$ gene expression. Endocr. Relat. Cancer 2015, 22, 505-517. [CrossRef] [PubMed]

31. Sun, H.; Wang, G.; Peng, Y.; Zeng, Y.; Zhu, Q.N.; Li, T.L.; Cai, J.Q.; Zhou, H.H.; Zhu, Y.S. H19 lncRNA mediates 17 $\beta$-estradiol-induced cell proliferation in MCF-7 breast cancer cells. Oncol. Rep. 2015, 33, 3045-3052. [CrossRef] [PubMed]

32. Tsang, W.P.; Enders, K.O.N.; Simon, S.M.N.; Jin, H.; Yu, J.; Sung, J.J.Y.; Kwok, T.T. Oncofetal H19-derived miR-675 regulates tumor suppressor RB in human colorectal cancer. Carcinogenesis 2010, 31, 350-358. [CrossRef] [PubMed]

33. Vennin, C.; Spruyt, N.; Dahmani, F.; Julien, S.; Bertucci, F.; Finetti, P.; Chassat, T.; Bourette, R.P.; Le Bourhis, X.; Adriaenssens, E. H19 non-coding RNA-derived miR-675 enhances tumorigenesis and metastasis of breast cancer cells by downregulating c-Cbl and Cbl-b. Oncotarget 2015, 6. [CrossRef] [PubMed]

34. Zhai, L.L.; Wang, P.; Zhou, L.Y.; Yin, J.Y.; Tang, Q.; Zhang, T.J.; Wang, Y.X.; Qin, Y.; Lin, J.; Deng, Z.Q. Over-expression of miR-675 in formalin-fixed paraffin-embedded (ffpe) tissues of breast cancer patients. Int. J. Clin. Exp. Med. 2015, 8, 11195-11201. [PubMed]

35. Cordero, F.; Ferrero, G.; Polidoro, S.; Fiorito, G.; Campanella, G.; Sacerdote, C.; Mattiello, A.; Masala, G.; Agnoli, C.; Frasca, G.; et al. Differentially methylated microRNAs in prediagnostic samples of subjects who developed breast cancer in the european prospective investigation into nutrition and cancer (epic-italy) cohort. Carcinogenesis 2015, 36, 1144-1153. [CrossRef] [PubMed]

36. Huang, Y.; Zheng, Y.; Jin, C.; Li, W. Long non-coding RNA H19 inhibits adipocyte differentiation of bone marrow mesenchymal stem cells through epigenetic modulation of histone deacetylases. Sci. Rep. 2016. [CrossRef] [PubMed]

37. Liu, L.; An, X.; Li, Z.; Song, Y.; Li, L.; Zuo, S.; Liu, N.; Yang, G.; Wang, H.; Cheng, X.; et al. The H19 long noncoding RNA is a novel negative regulator of cardiomyocyte hypertrophy. Cardiovasc. Res. 2016, 111, 56-65. [CrossRef] [PubMed]

38. Cai, B.; Ma, W.; Bi, C.; Yang, F.; Zhang, L.; Han, Z.; Huang, Q.; Ding, F.; Li, Y.; Yan, G.; et al. Long noncoding RNA $H 19$ mediates melatonin inhibition of premature senescence of C-kit ${ }^{+}$cardiac progenitor cells by promoting miR-675. J. Pineal Res. 2016, 61, 82-95. [CrossRef] [PubMed]

39. Costa, V.; Lo Dico, A.; Rizzo, A.; Rajata, F.; Tripodi, M.; Alessandro, R.; Conigliaro, A. MiR-675-5p supports hypoxia induced epithelial to mesenchymal transition in colon cancer cells. Oncotarget 2017, 8. [CrossRef] [PubMed]

40. Chen, S.; Dingfang, B.; Yuanyuan, M.; Zhu, J.; Chen, G.; Sun, L.; Li, T.; Pan, Y.; Wang, X.; et al. H19 Overexpression induces resistance to 1,25(OH)2D3 by targeting VDR through miR-675-5p in colon cancer cells. Neoplasia 2017, 19, 226-236. [CrossRef] [PubMed]

41. Li, X.; Hao, W.; Yao, B.; Xu, W.; Chen, J.; Zhou, X. lncRNA H19/miR-675 axis regulates cardiomyocyte apoptosis by targeting VDAC1 in diabetic cardiomyopathy. Sci. Rep. 2016, 6. [CrossRef] [PubMed]

42. Zhou, Y.W.; Zhang, H.; Duan, C.J.; Duan, C.J.; Gao, Y.; Cheng, Y.D.; He, D.; Li, R.; Zhang, C.F. miR-675-5p enhances tumorigenesis and metastasis of esophageal squamous cell carcinoma by targeting REPS2. Oncotarget 2016, 7. [CrossRef] [PubMed]

43. Li, H.; Yu, B.; Li, J.; Su, L.; Yan, M.; Zhu, Z.; Liu, B. Overexpression of lncRNA H19 enhances carcinogenesis and metastasis of gastric cancer. Oncotarget 2014, 5. [CrossRef] [PubMed]

44. Liu, G.; Xiang, T.; Wu, Q.F.; Wang, W.X. Long noncoding RNA H19-derived miR-675 enhances proliferation and invasion via RUNX1 in gastric cancer cells. Oncol. Res. 2016, 23. [CrossRef] [PubMed]

45. Zhuang, M.; Gao, W.; Xu, J.; Wang, P.; Shu, Y. The long non-coding RNA H19-derived miR-675 modulates human gastric cancer cell proliferation by targeting tumor suppressor RUNX1. Biochem. Biophys. Res. Commun. 2014, 448, 315-322. [CrossRef] [PubMed] 
46. Yan, J.; Zhang, Y.; She, Q.; Li, X.; Peng, L.; Wang, X.; Liu, S.; Shen, X.; Zhang, W.; Dong, Y.; et al. Long noncoding RNA H19/miR-675 axis promotes gastric cancer via FADD/Caspase 8/Caspase 3 signaling pathway. Cell. Physiol. Biochem. 2017, 42, 2364-2376. [CrossRef] [PubMed]

47. Shi, Y.; Wang, Y.; Wenkang, L.; Wang, P.; Tao, T.; Zhang, J.; Qian, J.; Liu, N.; You, Y. Long non-coding RNA H19 promotes glioma cell invasion by deriving miR-675. PLOS ONE 2014. [CrossRef] [PubMed]

48. Hernandez, J.M.; Elahi, A.; Clark, C.W.; Wang, J.; Humphries, L.A.; Centeno, B.; Bloom, G.; Fuchs, B.C.; Yeatman, T.; Shibata, D. miR-675 mediates downregulation of Twist1 and Rb in AFP-secreting hepatocellular carcinoma. Ann. Surg. Oncol. 2013, 20, 625-635. [CrossRef] [PubMed]

49. He, D.; Wang, J.; Zhang, C.; Shan, B.; Deng, X.; Li, B.; Zhou, Y.; Chen, W.; Hong, J.; Gao, Y.; et al. Down-regulation of miR-675-5p contributes to tumor progression and development by targeting pro-tumorigenic GPR55 in non-small cell lung cancer. Mol. Cancer 2015, 14. [CrossRef] [PubMed]

50. Huang, Y.; Zheng, Y.; Jia, L.; Li, W. Long Noncoding RNA H19 Promotes Osteoblast Differentiation via TGF- $31 / S m a d 3 / H D A C$ Signaling Pathway by Deriving miR-675: H19/miR-675 Promotes Osteogenesis. Stem Cells 2015, 33, 3481-3492. [CrossRef] [PubMed]

51. Gao, W.L.; Liu, M.; Yang, Y.; Xu, Y.; Li, R.; Deng, Q.; Sun, H.; Wang, S. The Imprinted H19 gene regulates human placental trophoblast cell proliferation via encoding miR-675 that targets nodal modulator 1 (NOMO1). RNA Biol. 2012, 9, 1002-1010. [CrossRef] [PubMed]

52. Sun, T.; Leung, F.; Lu, W. miR-9-5p, miR-675-5p and miR-138-5p damages the strontium and LRP5-mediated skeletal cell proliferation, differentiation, and adhesion. Int. J. Mol. Sci. 2016, 17. [CrossRef] [PubMed]

53. Dey, B.K.; Pfeifer, K.; Dutta, A. The H19 long noncoding RNA gives rise to microRNAs miR-675-3p and miR-675-5p to promote skeletal muscle differentiation and regeneration. Genes Dev. 2014, 28, 491-501. [CrossRef] [PubMed]

54. Chen, S.W.; Wang, P.Y.; Liu, Y.C.; Sun, L.; Zhu, J.; Zuo, S.; Ma, J.; Li, T.Y.; Zhang, J.L.; Chang, G.W.; et al. Effect of long noncoding RNA $H 19$ overexpression on intestinal barrier function and its potential role in the pathogenesis of ulcerative colitis. Inflamm. Bowel Dis. 2016, 22, 2582-2592. [CrossRef] [PubMed]

55. Kim, N.H.; Choi, S.H.; Lee, T.R.; Lee, C.H.; Lee, A.Y. Cadherin 11, a miR-675 target, induces N-cadherin expression and epithelial-mesenchymal transition in melasma. J. Investig. Dermatol. 2014, 134, 2967-2976. [CrossRef] [PubMed]

56. Kim, N.H.; Choi, S.H.; Kim, C.H.; Lee, C.H.; Lee, T.R.; Lee, A.Y. Reduced MiR-675 in exosome in H19 RNA-related melanogenesis via MITF as a direct target. J. Investig. Dermatol. 2014, 134, 1075-1082. [CrossRef] [PubMed]

57. Keniry, A.; Oxley, D.; Monnier, P.; Kyba, M.; Dandolo, L.; Smits, G.; Reik, W. The H19 lincRNA is a developmental reservoir of miR-675 that suppresses growth and Igf1r. Nat. Cell Biol. 2012, 14, 659-665. [CrossRef] [PubMed]

58. Adriaenssens, E.; Lottin, S.; Berteaux, N.; Hornez, L.; Fauquette, W.; Fafeur, V.; Peyrat, J.P.; Le Bourhis, X.; Hondermarck, H.; Coll, J.; et al. Cross-talk between mesenchyme and epithelium increases H19 gene expression during scattering and morphogenesis of epithelial cells. Exp. Cell Res. 2002, 275, 215-229. [CrossRef] [PubMed]

59. Tay, Y.; Kats, L.; Salmena, L.; Weiss, D.; Tan, S.M.; Ala, U.; Karreth, F.; Poliseno, L.; Provero, P.; Di Cunto, F.; et al. Coding-independent regulation of the tumor suppressor PTEN by competing endogenous mRNAs. Cell 2011, 147, 344-357. [CrossRef] [PubMed]

60. Peng, F.; Li, T.T.; Wang, K.L.; Xiao, G.Q.; Wang, J.H.; Zhao, H.D.; Kang, Z.J.; Fan, W.J.; Zhu, L.L.; Li, M.; et al. H19/let-7/LIN28 reciprocal negative regulatory circuit promotes breast cancer stem cell maintenance. Cell Death Dis. 2017, 8. [CrossRef] [PubMed]

61. Li, Z.; Li, Y.; Li, Y.; Ren, K.; Li, X.; Han, X.; Wang, J. Long non-coding RNA H19 promotes the proliferation and invasion of breast cancer through upregulating DNMT1 expression by sponging miR-152. J. Biochem. Mol. Toxicol. 2017. [CrossRef] [PubMed]

62. Zhou, W.; Ye, X.L.; Xu, J.; Cao, M.G.; Fang, Z.Y.; Li, L.Y.; Guan, G.H.; Liu, G.; Qian, Y.H.; Xie, D. The lncRNA H19 mediates breast cancer cell plasticity during EMT and MET plasticity by differentially sponging miR-200b/c and let-7b. Sci. Signal. 2017, 10. [CrossRef] [PubMed]

63. Zhao, T.F.; Jia, H.Z.; Zhang, Z.Z.; Zhao, X.S.; Zou, Y.F.; Zhang, J.; Chen, X.F. LncRNA H19 regulates ID2 expression through competitive binding to hsa-miR-19a/b in acute myelocytic leukemia. Mol. Med. Rep. 2017, 16, 3687-3693. [CrossRef] [PubMed] 
64. Lv, M.; Zhong, Z.; Huang, M.; Tian, Q.; Jiang, R.; Chen, J. lncRNA H19 regulates epithelial-mesenchymal transition and metastasis of bladder cancer by miR-29b-3p as competing endogenous RNA. Biochim. Biophys. Acta 2017, 1864, 1887-1899. [CrossRef] [PubMed]

65. Huang, Z.W.; Tian, L.H.; Yang, B.; Guo, R.M. Long noncoding RNA H19 acts as a competing endogenous RNA to mediate CTGF expression by sponging miR-455 in cardiac fibrosis. DNA Cell Biol. 2017. [CrossRef] [PubMed]

66. Ghazal, S.; McKinnon, B.; Zhou, J.; Mueller, M.; Men, Y.; Yuang, L.; Mueller, M.; Flannery, C.; Huang, Y.; Taylor, H.S. H19 lncRNA alters stromal cell growth via IGF signaling in the endometrium of women with endometriosis. EMBO Mol. Med. 2015, 7, 996-1003. [CrossRef] [PubMed]

67. Wu, W.; Hu, Q.; Nie, E.; Yu, T.; Wu, Y.; Zhi, T.; Jiang, K.; Shen, F.; Wang, Y.; Zhang, J.; et al. Hypoxia induces $H 19$ expression through direct and indirect Hif-1 $\alpha$ activity, promoting oncogenic effects in glioblastoma. Sci. Rep. 2017, 7. [CrossRef] [PubMed]

68. Kallen, A.N.; Zhou, X.B.; Xu, J.; Qiao, C.; Ma, J.; Yan, L.; Lu, L.; Liu, C.; Yi, J.S.; Zhang, H.; et al. The imprinted H19 IncRNA antagonizes Let-7 microRNAs. Mol. Cell 2013, 52, 101-112. [CrossRef] [PubMed]

69. Imig, J.; Brunschweiger, A.; Brümmer, A.; Guennewig, B.; Mittal, N.; Kishore, S.; Tsikrika, P.; Gerber, A.P.; Zavolan, M.; Hall, J. miR-CLIP Capture of a miRNA targetome uncovers a lincRNA H19-miR-106a interaction. Nat. Chem. Biol. 2014, 11, 107-114. [CrossRef] [PubMed]

70. Gao, Y.; Wu, F.; Zhou, J.; Yan, L.; Jurczak, J.; Lee, H.Y.; Yang, L.; Mueller, M.; Zhou, X.B.; Dandolo, L.; et al. The H19/let-7 double-negative feedback loop contributes to glucose metabolism in muscle cells. Nucleic Acids Res. 2014, 42, 13799-13811. [CrossRef] [PubMed]

71. Liang, W.C.; Fu, W.M.; Wang, F.B.; Sun, Y.X.; Xu, L.L.; Wong, C.W.; Chan, K.M.; Li, G.; Waye, M.M.Y.; Zhang, J.F. H19 Activates Wnt signaling and promotes osteoblast differentiation by functioning as a competing endogenous RNA. Sci. Rep. 2016, 6. [CrossRef] [PubMed]

72. Li, M.; Chen, H.; Zhao, Y.; Shuming, G.; Cai, C. H19 functions as a ceRNA in promoting metastasis through decreasing miR-200s activity in osteosarcoma. DNA Cell Biol. 2016, 35, 235-240. [CrossRef] [PubMed]

73. Liu, L.; Yang, J.; Zhu, X.; Li, D.; Lv, Z.; Zhang, X. Long noncoding RNA H19 competitively binds miR-17-5p to regulate YES1 expression in thyroid cancer. FEBS J. 2016, 283, 2326-2339. [CrossRef] [PubMed]

74. Luo, M.; Li, Z.; Wang, W.; Zeng, Y.; Liu, Z.; Qiu, J. Long non-coding RNA H19 increases bladder cancer metastasis by associating with EZH2 and inhibiting E-cadherin expression. Cancer Lett. 2013, 333, $213-221$. [CrossRef] [PubMed]

75. Zhuo, C.; Jiang, R.; Lin, X.; Shao, M. LncRNA H19 inhibits autophagy by epigenetically silencing of DIRAS3 in diabetic cardiomyopathy. Oncotarget 2017, 8. [CrossRef] [PubMed]

76. Monnier, P.; Martinet, C.; Pontis, J.; Stancheva, I.; Ait-Si-Ali, S.; Dandolo, L. H19 lncRNA controls gene expression of the imprinted gene network by recruiting MBD1. Proc. Natl. Acad. Sci. USA 2013, 110, 20693-20698. [CrossRef] [PubMed]

77. Zhou, J.; Yang, L.; Zhong, T.; Mueller, M.; Men, Y.; Zhang, N.; Xie, J.; Giang, K.; Chung, H.; Sun, X.; et al. H19 lncRNA alters DNA methylation genome wide by regulating S-adenosylhomocysteine hydrolase. Nat. Commun. 2015, 6. [CrossRef] [PubMed]

78. Deng, Q.; He, B.; Gao, T.; Pan, Y.; Sun, H.; Xu, Y.; Li, R.; Ying, H.; Wang, F.; Liu, X.; Chen, J.; et al. Up-regulation of $91 \mathrm{H}$ promotes tumor metastasis and predicts poor prognosis for patients with colorectal cancer. PLoS ONE 2014, 9. [CrossRef] [PubMed]

79. Vennin, C.; Spruyt, N.; Robin, Y.M.; Chassat, T.; Le Bourhis, X.; Adriaenssens, E. The long non-coding RNA $91 \mathrm{H}$ increases aggressive phenotype of breast cancer cells and up-regulates H19/IGF2 expression through epigenetic modifications. Cancer Lett. 2017, 385, 198-206. [CrossRef] [PubMed]

80. Berteaux, N.; Lottin, S.; Monté, D.; Pinte, S.; Quatannens, B.; Coll, J.; Hondermarck, H.; Curgy, J.J.; Dugimont, T.; Adriaenssens, E. H19 mRNA-like noncoding RNA promotes breast cancer cell proliferation through positive control by E2F1. J. Biol. Chem. 2005, 280, 29625-29636. [CrossRef] [PubMed]

81. Barsyte-Lovejoy, D.; Lau, S.K.; Boutros, P.C.; Khosravi, F.; Jurisica, I.; Andrulis, I.L.; Tsao, M.S.; Penn, L.Z. The c-Myc oncogene directly induces the $H 19$ noncoding RNA by allele-specific binding to potentiate tumorigenesis. Cancer Res. 2006, 66, 5330-5337. [CrossRef] [PubMed]

82. Dugimont, T.; Montpellier, C.; Adriaenssens, E.; Lottin, S.; Dumont, L.; Iotsova, V.; Lagrou, C.; Stéhelin, D.; Coll, J.; Curgy, J.J. The H19 TATA-less promoter is efficiently repressed by wild-type tumor suppressor gene product P53. Oncogene 1998, 16, 2395-2401. [CrossRef] [PubMed] 
83. Yang, F.; Bi, J.; Xue, X.; Zheng, L.; Zhi, K.; Hua, J.; Fang, G. Up-regulated long non-coding RNA H19 Contributes to proliferation of gastric cancer cells. FEBS J. 2012, 279, 3159-3165. [CrossRef] [PubMed]

84. Zhang, K.; Luo, Z.; Zhang, Y.; Li, Z.; Lichun, W.; Lian, L.; Yang, J.; Song, X.; Liu, J. Circulating lncRNA H19 in plasma as a novel biomarker for breast cancer. Cancer Biomark. 2016, 17, 187-194. [CrossRef] [PubMed]

85. Zhou, X.; Yin, C.; Dang, Y.; Ye, F.; Zhang, G. Identification of the long non-coding RNA H19 in plasma as a novel biomarker for diagnosis of gastric cancer. Sci. Rep. 2015, 5. [CrossRef] [PubMed]

86. Chen, J.S.; Wang, Y.F.; Zhang, X.Q.; Lv, J.M.; Li, Y.; Liu, X.X.; Xu, T.P. H19 serves as a diagnostic biomarker and up-regulation of $H 19$ expression contributes to poor prognosis in patients with gastric cancer. Neoplasma 2016, 63, 223-230. [CrossRef] [PubMed]

87. Gofrit, O.N.; Benjamin, S.; Halachmi, S.; Leibovitch, I.; Dotan, Z.; Lamm, D.L.; Ehrlich, N.; Yutkin, V.; Ben-Am, M.; Hocherg, A. DNA based therapy with diphtheria toxin-A BC-819: A phase 2b marker lesion trial in patients with intermediate risk nonmuscle invasive bladder cancer. J. Urol. 2014, 191, 1697-1702. [CrossRef] [PubMed]

88. Lavie, O.; Edelman, D.; Levy, T.; Fishman, A.; Hubert, A.; Segev, Y.; Raveh, E.; Gilon, M.; Hichberg, A. A phase $1 / 2 a$, dose-escalation, safety, pharmacokinetic, and preliminary efficacy study of intraperitoneal administration of BC-819 (H19-DTA) in subjects with recurrent ovarian/peritoneal cancer. Arch. Gynecol. Obstet. 2017, 295, 751-761. [CrossRef] [PubMed]

(C) 2017 by the authors. Licensee MDPI, Basel, Switzerland. This article is an open access article distributed under the terms and conditions of the Creative Commons Attribution (CC BY) license (http:/ / creativecommons.org/licenses/by/4.0/). 